\title{
NARRATIVE STRATEGIES BY CREATING A REALITY TELEVISION ON MODERN RUSSIAN TV
}

Lilya R. Khuzeeva ${ }^{1}$

\begin{abstract}
Narratology as a general narrative theory applies to the analysis of artistic and historical texts. At the same time, it can be successfully applied to the analysis of television scenarios, because it allows you to see the general course of the proposed history, determine the television picture of the world, and, perhaps, more broadly, media reality. The reconstruction of the TV show model can be useful for the subsequent implementation in the practical activities on television when creating original

narrative strategies were formulated. A consistent study of the implementation of the strategy led to a general conclusion about which strategy is leading and decisive for this type of reality show. Identification of narrative strategies allows you to expand the boundaries of potential project changes in the future, and also stimulates the search for optimal ways to implement various television functions, including regulatory, social and educational, and others.
\end{abstract} projects. Based on the narratological analysis of the two seasons of the reality show "Ladette" (they appeared on the Russian TV channel "Piatnitsa" in 20162017), the author identifies the composition of the program and narrative strategies that implement various types of narrators. In the course of the study, groups of narrators were identified, their roles in the development of the plot were defined, and their
Keywords: television, reality television, reality shows, narratology, strategy, narration, composition.

\section{Introduction}

Television creates media reality, not identical to the reality where every single subject of mass communication exists. Due to careful screening, the use of editing techniques and sound design

\footnotetext{
${ }^{1}$ Kazan Federal University. e-mail: Lilija.Khuzeeva@mail.ru. Tel.: +79053197063
} 


\section{Periódico do Núcleo de Estudos e Pesquisas sobre Gênero e Direito Centro de Ciências Jurídicas - Universidade Federal da Paraíba V. 8 - No 04 - Ano 2019 - Special Edition ISSN | 2179-7137 | http://periodicos.ufpb.br/ojs2/index.php/ged/index}

television can create a certain picture of the world. At the same time, as noted in the studies, a separate program does not create a holistic picture of the world, but represents its separate fragment, the content of which translates the idea of the program authors and the tasks facing them [1]. It is precisely in accordance with the tasks of a particular TV program that its composition is built, the content is determined, the necessary and sufficient figurative and expressive means are selected. Based on the opinion of S. Hall [2, 3] that the message in the media sphere undergoes transformation both at the stage of its creation and in the process of perception, as well as on J. Fiske's statement that "television does not represent (or represents) a fragment of reality, but rather produces or constructs it" [4], we can safely assume that the transfer of any genre on television does not recreate reality as much as recreates it, based on real facts.

In this context, the reality show genre is of particular interest, and its popularity is constantly increasing on modern Russian television. A reality show (reality television) is an entertainment television program, the plot of which is the demonstration of the actions of a group of people in a closeto-life environment. Despite the freedom of behavior of participants and the development of events declared by the genre, there is no doubt about the fact that the script is carefully prepared, since it lays down the main narrative strategies, as well as the ways to implement communicative tasks.

This paper discusses the issue of narrative strategies and the compositional construction of the reality show "Ladette" on the channel "Piatnitsa" (2 seasons aired in 2016 and 2017). In general, the reality show model in its most general form is comparable to the model of a work of art in which the author creates the art world, his laws of time and space, characters, sets a certain composition, defines the narrator - all the essential elements of a work of art. Consequently, the approaches developed in narratology may be applicable to the reality show scenario as well as to the final television production.

The results of the study can be used in the development of training courses on drama and screenwriting for television, as well as in actual practice of creating original scripts for television programs. 


\section{Periódico do Núcleo de Estudos e Pesquisas sobre Gênero e Direito Centro de Ciências Jurídicas - Universidade Federal da Paraíba V. 8 - No 04 - Ano 2019 - Special Edition ISSN | 2179-7137 | http://periodicos.ufpb.br/ojs2/index.php/ged/index}

\section{Methods}

This research used general scientific methods: analysis, abstraction, induction, modeling. The main special method was the narratological analysis, which starts from the works by $\mathrm{V}$. Schmidt and the structuralists. To determine the main narrative strategies, theoretical conclusions from the works by V.I. Tiupa were used.

\section{Results and discussion}

In autumn 2016 and 2017, the entertainment channel "Piatnitsa" broadcasted two seasons of the reality show "Ladette", which is the analogue of the British show "Ladette to Lady" (broadcasted in 2005 - 2010). It is about girls with a low level of general culture of behavior, who have alcohol, nicotine, or other types of addiction, but who have decided to radically change their lives.

Simulation of reality in the project "Ladette" operates according to certain rules and is essentially a game in its understanding, which was given by the Dutch culture researcher J. Heizing [5]. A reality show with full confidence can be attributed to the narrative text [6, 7], since both the script and the final product possess the key features of the narrative.

1. Eventuality. As noted by Iu.M. Lotman, "an event in the text is the movement of a character across the border of a semantic field" [8]. The reality show "Ladette" on the TV channel "Piatnitsa" preserves the traditional three-part structure: a) the heroine is in her usual way of life (social "bottom") and is guided by her usual system of values; b) the heroine "crosses the border", enters the project (the socalled "Lady School"), where the previous order of her life collapses; c) the heroine changes in order to acquire new values and live a different life.

2. Fictionality. Despite the general focus of reality shows on the viability, its conventionality is beyond doubt. In a television narrative, the laws of space and time are violated, when, for example, thanks to editing, a retrospective commentary on a specific event can be shown in parallel with the screening of what is happening or even before it is shown in order to retain the audience and create intrigue.

3. The significance of the form of the final television product. Each element when assembling the final 


\section{Periódico do Núcleo de Estudos e Pesquisas sobre Gênero e Direito Centro de Ciências Jurídicas - Universidade Federal da Paraíba V. 8 - No 04 - Ano 2019 - Special Edition ISSN | 2179-7137 | http://periodicos.ufpb.br/ojs2/index.php/ged/index}

version of the release acquires meaning for the formation of the perception of content by the viewer. The selection of personnel, replicas, the construction of the drama of the release - all this works to implement narrative strategies.

Reconstructing the original script, we can highlight its main elements:

1) "advertising card" (profile) of each participant;

2) challenges / tests aimed at adjusting the behavior of participants;

3) comments of participants, teachers and the psychologist;

"Advertising card" (profile) is the representation of the participant, which is removed before the beginning of life in the "Lady School". In the reality show "Ladette" the profile performs the function of exposure, acquaintance with the hero. In this case, the profile is shown not from the first minutes of the show, but after the first (as a rule) appearance of the heroine in the show. Compulsory components in the representation of the heroine is a short story about her life before the project, about difficult, mostly dramatic relations with parents or children. The focus is on the conflict of the heroine with the world around her (external conflict) and with herself (internal conflict), as well as the desire to change her life (including solving problems with alcohol, nicotine and other types of addictions) due to her participation in the project.

The appearance of teachers in the show is always associated with the test. Their functions on the project include explaining the challenges for the week, monitoring their implementation, commenting and evaluating the behavior of the project participants and their success over the allotted time. In their comments, each of the three teachers determines whether the past week was useful for the participant, whether the heroine has learned to deal with bad habits, and whether there is progress towards changing her behavior.

One of the main and permanent elements of the scenario of the reality show "Ladette", revealing the identity of the participants, as well as creating an intrigue and a comprehensive picture of what is happening on the screen, is a retrospective commenting by the participant of an event on the set or her decisions. On the one hand, this block in the structure of the plot of the program slows down the course of the narration, 


\section{Periódico do Núcleo de Estudos e Pesquisas sobre Gênero e Direito Centro de Ciências Jurídicas - Universidade Federal da Paraíba V. 8 - No 04 - Ano 2019 - Special Edition ISSN | 2179-7137 | http://periodicos.ufpb.br/ojs2/index.php/ged/index}

on the other hand, it provides an opportunity for self-disclosure of the hero. However, this is not a monologue to the camera, because on the set the participant of the reality show communicates with one of the editors and answers his questions that are not part of the final layout of the program, but help to build the necessary dramatic line, identify and aggravate the conflicts between the participants, thereby strengthening the most emotional impact of the transmission on the audience.

In a close manner, the composition of each release and the entire project "Ladette" is associated with the narrator of this story. It should be noted that this reality show includes several types of narrators. The narrator, the viewer meets first, is a narrator whom the viewer does not see, but only hears his voice behind the scenes. He presents participants, teachers and guests to the audience, reports on the rules of a particular task, announces events. This narrator is not included in the process, knows more than the viewer, for example, how the series and (or) the project will end, how the participants will behave, so they can give comments
386 regarding their status or decisions, that is, it is implicit and non-diegetic.

Another type of narrator is the teachers of the "Lady School" (they also include invited guests and a psychologist). They are included in the process, but they are not always with the participants, so they can be attributed to explicit diegetic narrators. Their function is to evaluate and correct the behavior of participants, relating it to generally accepted norms. Being a kind of intermediaries between the participants and the audience, they are at the same time the carriers of knowledge and pass them not only to the participants, but also to the audience.

The third type of narrator is the project participants themselves. The viewer not only watches their behavior, but also hears the comments in the interview. That is, in this way, a polyphony of opinions is created, which allows the audience to form an aggregate view of the project participants, of the reality show itself. Heroines also belong to explicit diegetic narrators.

Finally, another type of narrator should be distinguished, the presence of which is not quite obvious to many viewers, but it is an obligatory part of the 


\section{Periódico do Núcleo de Estudos e Pesquisas sobre Gênero e Direito Centro de Ciências Jurídicas - Universidade Federal da Paraíba V. 8 - No 04 - Ano 2019 - Special Edition ISSN | 2179-7137 | http://periodicos.ufpb.br/ojs2/index.php/ged/index}

program and largely determines its course - this is an implicit non-diegetic narrator that can be considered primary, framing the whole story. This is a much more complicated construction for analysis, since the creation of the script, both initial and final, is the collective work of both the scriptwriters, the director, the producer and other participants in the shooting process. That is, this narrator is a kind of abstract collective formation, thanks to which the dynamics of the project, its overall strategy are built, individual situations are constructed, specific plots are programmed.

Frequent change of narrator in each release allows achieving polyphonic sound, which, on the one hand, creates the illusion of objective narration (since the viewer hears the opinions of different participants about the same event or phenomenon), and on the other hand, allows the primary narrator to program possible options of interpreting the behavior of the project participants.

\section{Summary}

If we consider the narrative strategies of various narrators, we can see a comprehensive picture of their interaction. At this stage of the study, we deliberately do not delimit the narrative strategies of individual participants in a reality show, since in this case such detailing is not necessary. The individual strategies of each heroine are of interest, first of all, for analyzing them from the point of view of psychology. In this paper we consider them as a generalized type of this type of narrator.

V.I. Tiupa, interpreting the concept of narrative strategy, indicates that it "consists in positioning the cognitive subject of communication (the author) of a verbal subject (narrator) with respect to objects and recipients of storytelling" [9] in relation to the history of the picture of the world, as well as intrigue, designed to keep the addressee's attention [10]. V.I. Tiupa reveals the basic narrative strategies that exist in the history of culture, emphasizing that in the culture of the New Age they are present simultaneously and actively interact with each other. Based on the theoretical conclusions of the scientist, we apply them to the analysis of the narrative in the reality show "Ladette".

First of all, we note the narrative strategy of the implicit and non-diegetic 


\section{Periódico do Núcleo de Estudos e Pesquisas sobre Gênero e Direito Centro de Ciências Jurídicas - Universidade Federal da Paraíba V. 8 - No 04 - Ano 2019 - Special Edition ISSN | 2179-7137 | http://periodicos.ufpb.br/ojs2/index.php/ged/index}

narrator, whose voice is heard by the audience. Model of his narration, if we turn to the theoretical reflections by V.I. Tiupa, can by partly put in parallel with the strategy, which is revealed through the mythological picture of the world, where the heroes do what they have to (according to their fate), that is, the world "does not transform, it only reveals itself in its truth" [9]. Indeed, for this narrator, the events have already passed, he has to some extent an epic look, he knows the result of the series and (or) the project, for him there is no surprise or intrigue (according to the research of V.I. Tiupa, this is the first narrative strategy).

Next, we shall turn to the definition of the narrative strategy of the teachers of the "Lady School". They demonstrate the strategy that V.I. Tiupa (based on the research by Iu.M. Lotman and Kh. Perelman) characterizes, through the imperative nature of the picture of the world, the modality of authoritarian persuasion and the didactic intrigue of obligation. "Leaving an arbitrarily vast space for freedom of delusions and mistakes, the narration of a parable type presupposes the existence of the only right path," [9] writes the researcher (the second type of strategy). This correlates with the position of the teacher as a narrator. Acknowledging the right of every person to make mistakes, they broadcast the only true model of life, seeking to replace with it the former way of life of the heroines of the project. Authoritarian persuasion is often manifested in rigorous assessments and criticism of the mistakes of project participants. Despite the fact that we have united the teachers and the psychologist of the project into one type of narrator, a slight clarification can be made that the psychologist will be more prone to a strategy that includes understanding rather than conviction.

The narrative strategy of the direct participants of the reality show "Ladette" will be determined through the occasional picture of the world, where "the adventurous event chain is formed by private initiative, ingenuity or mistakes of the actors who are free in their wills, and also by coincidence, the play of chance" [9] (third type of). The heroines of reality shows act independently in the framework of often spontaneously developing routine and communicative situations. The participants as narrators do not have a 


\section{Periódico do Núcleo de Estudos e Pesquisas sobre Gênero e Direito Centro de Ciências Jurídicas - Universidade Federal da Paraíba V. 8 - No 04 - Ano 2019 - Special Edition ISSN | 2179-7137 | http://periodicos.ufpb.br/ojs2/index.php/ged/index}

broad vision of the situation, they are as personalized as possible, that is, they have bright and individual personal characteristics. In this narrative, events are often organized on a cumulative principle, when one event is "strung" on another without always having a causal relationship between them.

As part of the development of the reality show "Ladette" one can see the constant collision of the second and third strategies and the mandatory conflict between them. The answer to the question of what this conflict should lead to is possible if we look at the task that the producers of the reality show set themselves: "to release real ladies into the real life" [11]. This position can be correlated with a strategy in which a probabilistic picture of the world is realized, within which a person has freedom of choice (working on himself and getting better or remaining the same himself), but at the same time he is responsible of whether he can use his chance and change his fate (the fourth type of narrative strategy). Here there is a search for self-identity, the disclosure of oneself as an individual. This is the way to define the strategy of the primary narrator, which is the collective creator of the project. The final version of the broadcasts is based on the "problem - the situation of moral choice - taking responsibility - the result of the choice" scheme. The winner of the project becomes a heroine, able to realize the result of her actions and take responsibility for them.

Thus, to win the reality show "Ladette", the most important and necessary condition is the change of the narrative strategy of the explicit diegetic narrator, who is the hero of the project, from the third to the fourth, but with the constant narrative strategy of the teachers (the second strategy).

\section{Conclusion}

The narrative strategies identified in the framework of a concrete reality show, their interaction and conflict once again underline their universality and multiplicity of options for successful use in various television programs. As part of the overall picture of studying television, the study of storytelling strategies in different television genres is necessary, since it is directly connected with the process of studying communication. Despite the fact that television communication is distant, 


\section{Periódico do Núcleo de Estudos e Pesquisas sobre Gênero e Direito Centro de Ciências Jurídicas - Universidade Federal da Paraíba V. 8 - No 04 - Ano 2019 - Special Edition ISSN | 2179-7137 | http://periodicos.ufpb.br/ojs2/index.php/ged/index}

television constantly seeks to increase the degree of interactive cooperation with its audience. This leads to the complication of the communication process in terms of its organization and modeling, however, it has undeniable benefits for the development of television and video production itself. The identification of narrative strategies in television discourse allows you to further create a separate typology (by analogy with the fundamental works by V.Ia. Propp, Georges Polti, and others), to expand the theoretical understanding of the patterns of television communication. Another challenge for further research may be related to establishing the relationship between narrative strategies and the popularity of the program among the audience. All this will allow deepening knowledge about the forms and methods of influence on the audience, the possibilities of predicting the reaction and the perception of video information by the audience.

\section{Acknowledgements}

The work is performed according to the Russian Government Program of
390

Competitive Growth of Kazan Federal University.

\section{References}

Novikova A.A. The television picture of the world as an object of research in journalism / A.A. Novikova. - Bulletin of RSUH. Series: History. Philology. Culturology. Orientalism. - 2012. No.13. - p. 217-226.

Hall S. Encoding, decoding in the television discourse. In Hall, S., Hobson, D. \& Lowe, P. (eds). Culture, Media, Language. London: Hutchinson. 1980. Pp. 128-138.

McQual, D. \& Windhal, S. Communication Models for the Study of Mass Communication. 2nd Edition. Longman, 1993. Pp. 146-147.

Fiske J. Television Culture. New York, 1987. Reprinted 2006. P. 84-107.

Huizinga J. Homo Ludens; Articles on the history of culture. / Transl. from Dutch by D.V. Silvestrov - M.: Progress - Tradition, 1997. - 416 p. 
Periódico do Núcleo de Estudos e Pesquisas sobre Gênero e Direito Centro de Ciências Jurídicas - Universidade Federal da Paraíba V. 8 - $\mathrm{N}^{\mathrm{o}} 04$ - Ano 2019 - Special Edition ISSN | 2179-7137 | http://periodicos.ufpb.br/ojs2/index.php/ged/index

Schmid W. Narratology. An Introduction, Berlin \& New York: Walter de Gruyter 2010. 265 p.

Tjupa, V. Narrative strategies / Tjupa V. // Handbook of Narratology (2nd edition) / ed. by P. Hьhn, J. C. Meister, J. Pier, W. Schmid. - Berlin; Boston: Walter de Gruyter GmbH, 2014. - P. 564-575.

Lotman Iu.M. The structure of the literary text // Lotman Iu.M. About art. St.P.: “Art - St.P.”, 1998. - 704 p.

Tiupa V.I. The narrative strategy of the novel / V.I. Tiupa / / New Philological Bulletin. - 2011. - No.3 (18). - p. 8-25.

Zhilicheva G.A. Narrative strategies in the genre structure of the novel (on the material of Russian prose of the 19201950s): Thesis of Doctor of Philological Sciences: 10.01.08 / G.A. Zhilicheva. M., 2015. - 429 p.

About the project "Ladette" [electronic resource] URL: https://patsanki.friday.ru 